\title{
Fumarole compositions and mercury emissions from the Tatun Volcanic Field, Taiwan: Results from multi-component gas analyser, portable mercury spectrometer and direct sampling techniques
}

\author{
M.L.I. Witt ${ }^{\text {a,* }}$, T.P. Fischer ${ }^{\text {b }}$, D.M. Pyle ${ }^{\text {a }}$, T.F. Yang ${ }^{\text {c }}$, G.F. Zellmer ${ }^{\mathrm{d}}$ \\ a Department of Earth Sciences, University of Oxford, Parks Road, Oxford OX1 3PR, UK \\ b Department of Earth and Planetary Sciences, University of New Mexico, Albuquerque, NM 87131-1116, USA \\ ${ }^{\mathrm{c}}$ Department of Geosciences, National Taiwan University, Taipei 10699, Taiwan, ROC \\ d Institute of Earth Sciences, Academia Sinica, 128 Academia Road, Sec. 2, Nankang, Taipei 11529, Taiwan, ROC
}

\section{A R T I C L E I N F O}

Article history:

Received 18 September 2007

Accepted 23 June 2008

Available online 16 July 2008

Keywords:

gaseous elemental mercury

Multi-GAS sensor

volcanic flux

emissions

atmosphere

\begin{abstract}
A B S T R A C T
Gas emissions from Tatun volcanic group, northern Taiwan, were studied for the first time using a multicomponent gas analyser system (Multi-GAS) in combination with Giggenbach flask methods at fumaroles and mud pools at Da-you-keng (DYK) and Geng-tze-ping (GZP). $\mathrm{CO}_{2} / \mathrm{S}$ molar ratios observed at DYK ranged from 3-17, similar ratios were observed using a Multi-GAS sensor box of 8-16. $\mathrm{SO}_{2}$ at GZP was low, higher concentrations were observed at DYK where $\mathrm{SO}_{2} / \mathrm{H}_{2} \mathrm{~S}$ ratios were close to 1 for both methods. A lower $\mathrm{CO}_{2} /$ $\mathrm{H}_{2} \mathrm{~S}$ ratio was measured via Giggenbach flask sampling (7.2) than was found in the plume using the gas sensor at GZP (9.2). This may reflect rapid oxidation of $\mathrm{H}_{2} \mathrm{~S}$ as it mixes with background air. Gaseous elemental mercury (GEM) levels were observed in the fumarole gases using a portable mercury spectrometer. These are the first such measurements of mercury at Tatun. Mean GEM concentrations in the fumarole plumes were $\sim 20 \mathrm{ng} \mathrm{m^{-3 }}$, with much higher concentrations observed close to the ground (mean [GEM] 130 and $290 \mathrm{ng} \mathrm{m}^{-3}$ at DYK and GZP, respectively). The GEM in the fumarole plume was elevated above concentrations in industrial/urban air in northern Taiwan and the increase in GEM observed when the instrument was lowered suggests high levels of mercury are present in the surrounding ground surface. The $\mathrm{GEM} / \mathrm{CO}_{2}\left(10^{-8}\right)$ and $\mathrm{GEM} / \mathrm{S}\left(10^{-6}\right)$ ratios observed in the fumarole gases were comparable to those observed at other low-temperature fumaroles. Combining the $\mathrm{Hg} / \mathrm{CO}_{2}$ ratio with a previous $\mathrm{CO}_{2}$ flux value for the area, the annual GEM flux from the Tatun field is estimated as $5-50 \mathrm{~kg} / \mathrm{year}$.
\end{abstract}

(c) 2008 Elsevier B.V. All rights reserved.

\section{Introduction}

The Tatun volcanic group lies in northern Taiwan just north of the Taipei basin, and includes more than 20 Quaternary volcanic centres, predominantly of calc-alkaline andesites (e.g. Chen and Wu, 1971). The Tatun volcanoes are generally considered to be dormant, with no evidence of eruptions within the past $20 \mathrm{ka}$, although recent seismic and geochemical data (e.g. ${ }^{3} \mathrm{He} /{ }^{4} \mathrm{He}$ ratios of up to $6.8 R / R_{A}$ ) suggest that there may still be an active magmatic source beneath the Tatun field (Song et al., 2000; Chen and Lin, 2002). At the present day, hot springs and gas fumaroles are found throughout the volcanic field (Fig. 1).

The chemistry of fumarole gases is related to the activity of the underlying volcanic system, and studies of fumarole chemistry have proved helpful in understanding both the sources of volcanic fluids, and for volcano surveillance (e.g. Giggenbach, 1992; Chiodini et al., 1995; Fischer et al., 1997). Study of the gases emitted may also be of interest in terms of their impact as atmospheric pollutants (e.g. Mao et al., 2005;

\footnotetext{
* Corresponding author. Tel.: +44 1865 282122; fax: +44 1865272072.

E-mail address: melanie.witt@earth.ox.ac.uk (M.L.I. Witt).
}

Fulignati et al., 2006). Mercury is a metal of particular interest due to its high toxicity, its volatility and long atmospheric lifetime (Mason et al., 1994; Fitzgerald et al., 1998). In the atmosphere, mercury is mainly found as the relatively inert form of gaseous elemental mercury (GEM). While anthropogenic sources of atmospheric mercury remain significant (Hylander and Meili, 2003), it is also clear that volcanic and geothermal areas may be important natural sources of mercury, since $\mathrm{Hg}$ concentrations in volcanic gases are significantly enhanced above background levels (e.g. Varekamp and Buseck, 1981; Ferrara et al., 2000; Bagnato et al., 2007). However, global volcanic Hg fluxes remain poorly constrained, and there is a need for continuing work to characterise both low-temperature (fumarolic) and high-temperature volcanic emissions (e.g. Pyle and Mather, 2003).

Fumarolic fluids of the Tatun field have been well characterised by Lee et al. (2005), using the methods developed by Giggenbach (1975) in which gases are collected for subsequent analysis. The Giggenbach flask technique is well established and enables determination of a large number of chemicals within fumarole gases over a specific time period; however the time-consuming laboratory based measurements prevent real-time observations. More recently, Lan et al. (2007) 


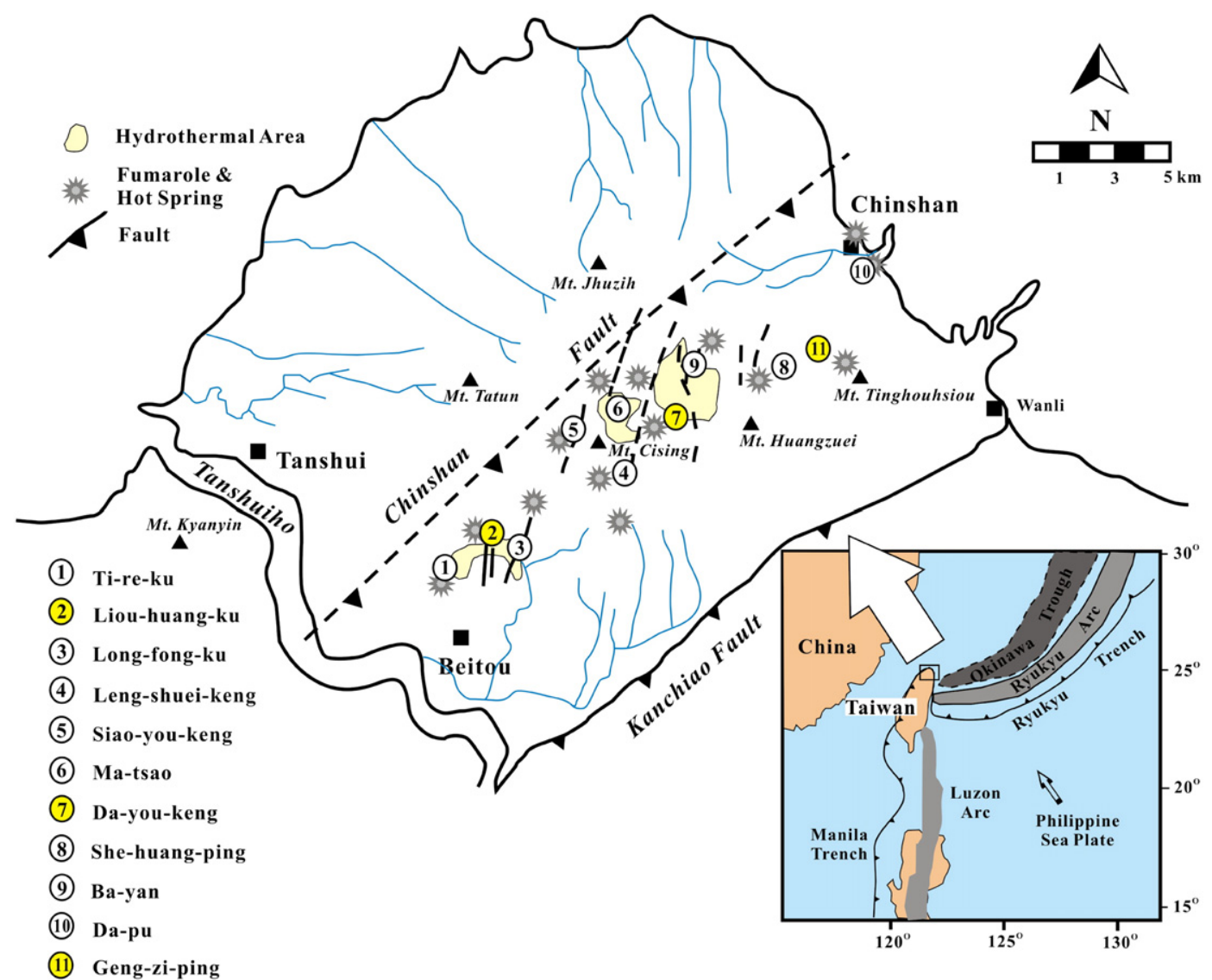

Fig. 1. Location of the Tatun Volcanic Field and the active fumarole sites within the field (adapted from Lee et al., 2005).

determined the soil $\mathrm{CO}_{2}$ flux from the area, using closed-chamber methods (Chiodini et al., 1998). Here, we report real-time measurements of fumarole gas compositions using a portable multi-sensor gas analyser (Aiuppa et al., 2005; Shinohara, 2005), which was deployed at active fumaroles around Tatun in parallel with a portable mercury analyser, and direct gas sampling. These complementary approaches allow us to investigate changes in gas compositions on short timescales (s); to monitor the effects of mixing of fumarole gases with background air, and to compare directly real-time and timeintegrated techniques for the analysis of volcanic fluid compositions.

\section{Methods}

Fumarole gases were sampled over several days during April 2007 at a number of sites within the Tatun Volcanic Field (Fig. 1). In particular, we focussed on measurements at the largest fumaroles of the Tatun group, at Da-you-keng (DYK). Measurements were also made at fumaroles and bubbling mud pools at Geng-tze-ping (GZP), a site close to DYK with similar chemistry. The fumaroles investigated all had similar temperatures of around $100{ }^{\circ} \mathrm{C}$. Helium isotope measurements suggest a magmatic source may be present below DYK. It is here that the highest ${ }^{3} \mathrm{He} /{ }^{4} \mathrm{He}$ ratios are observed $\left(6.8 R / R_{A}\right.$; Yang et al., 1999; Lan et al., 2007); while at locations on either side of DYK the gases become progressively less magmatic as distance increases. GZP is located close to DKY and has the second highest ${ }^{3} \mathrm{He} /{ }^{4} \mathrm{He}$ ratio of the sites studied (Yang et al., 2003). The soil $\mathrm{CO}_{2}$ flux from this site is also lower than at DYK.

\subsection{Gaseous elemental mercury (GEM)}

Continuous mercury measurements were made using a Lumex $915+$ portable mercury vapour analyser. The analyser sampled air at
$201 \mathrm{~min}^{-1}$ through a dust filter to remove particles from the air flow. The analyser uses differential atomic absorption spectrometry with correction for background via the Zeeman Effect (Zeeman Atomic Absorption Spectrometry with High Frequency Modulation of Light Polarisation) (Sholupov et al., 2004). During sampling a zero correction was carried out to reset the baseline every 5 min by switching the airflow through a mercury absorption filter. The instrument software then corrects for baseline drift. Only gaseous elemental mercury is detected by the Lumex instrument. The detection limit was $2 \mathrm{ng} \mathrm{m}^{-3}$ and the instrument has an accuracy of $20 \%$. We have reported elsewhere similar measurements from volcanic fumaroles in Italy and Nicaragua made using a Lumex, and detailed comparisons with side-by-side gold trap measurements (Aiuppa et al., 2007a; Witt et al., 2008).

Mercury concentrations were monitored in the fumarole gases at DYK and GZP using the Lumex mercury analyser. These are the first such measurements carried out at this location. The advantage of this technique is that it can be carried out at low-temperature fumaroles in the presence of high levels of humidity and $\mathrm{H}_{2} \mathrm{~S}$. Gold-coated sand traps have been used in a number of studies at similar volcanic sites by passing air over the trap so that gaseous mercury is collected as a gold amalgam for later analysis (e.g. Engle et al., 2006; Aiuppa et al., 2007a; Bagnato et al., 2007). Use of gold traps is difficult in such conditions as high levels of $\mathrm{H}_{2} \mathrm{~S}$ can lead to passivation (Schroeder et al., 1995).

\subsection{Multi Multi-component gas analyser system (Multi-GAS)}

Concentrations of $\mathrm{SO}_{2}, \mathrm{CO}_{2}$, and $\mathrm{H}_{2} \mathrm{~S}$ were monitored using a Multi multi-component gas analyser system (Multi-GAS) (Aiuppa et al., 2005; Shinohara, 2005). Gas was drawn into the sampler using an airchek 500 pump at $0.81 \mathrm{~min}^{-1}$ through a $0.2 \mu \mathrm{m}$ Teflon membrane particle filter, passed through a $\mathrm{CO}_{2}$ infrared detector (Gascard II 
Edinburgh instruments; 0-5000 ppm) followed by a series of electrochemical sensors which detected $\mathrm{SO}_{2}(0-100 \mathrm{ppm})$ and $\mathrm{H}_{2} \mathrm{~S}$ (0-50 ppm) (Membrapor). The $\mathrm{SO}_{2}$ sensor had an inbuilt filter to prevent interference from $\mathrm{H}_{2} \mathrm{~S}$. Temperature and relative humidity were measured with an external probe (Rotronics hydroclip combined $\mathrm{RH} /$ temp probe), and the whole system was housed in a weather-proof box mounted on a backpack frame. Sensors were calibrated, before and after fieldwork, with calibration gases (100 ppm $\mathrm{SO}_{2}, 50 \mathrm{ppm} \mathrm{H}_{2} \mathrm{~S}$ and $4000 \mathrm{ppm} \mathrm{CO}_{2}$ supplied to $2 \%$ accuracy) mixed with ultrapure nitrogen to provide a range of concentrations. The $\mathrm{CO}_{2}$ and electrochemical sensors have an accuracy of $2 \%$ quoted by Membrapor. The calibration gases also enabled cross-sensitivity of the $\mathrm{H}_{2} \mathrm{~S}$ sensor to $\mathrm{SO}_{2}$ to be evaluated. The response of the $\mathrm{H}_{2} \mathrm{~S}$ sensor to $\mathrm{SO}_{2}$ gas was established during calibration (0.08-0.18 ppm $\mathrm{H}_{2} \mathrm{~S} / \mathrm{ppm} \mathrm{SO}_{2}$ depending on individual sensor). The $\mathrm{SO}_{2}$ concentration detected in the field was used at each time point to subtract the contribution to the $\mathrm{H}_{2} \mathrm{~S}$ signal. The other cross-sensitivities of the sensors were found to be negligible during calibration.

\subsection{Direct gas sampling using Giggenbach flasks}

Samples were collected using the standard Giggenbach sample method (Giggenbach and Gougel, 1989) where a titanium tube is inserted into the fumarole and connected to an evacuated glass bottle via Tygon tubing. The evacuated sample bottle contains approximately $50 \mathrm{ml} 5 \mathrm{~N} \mathrm{NaOH}$. Acid gases absorb in the caustic solution and are analyzed by standard wet chemical techniques. Non-reactive gases are concentrated in the headspace of the bottle and analyzed by gas chromatography. The samples were analyzed in the volcanic and hydrothermal fluids analyses laboratory at the University of New Mexico using a gas chromatography system and standard wet chemical techniques (Zimmer et al., 2004).

\section{Results and discussion}

The Multi-GAS system has been previously employed at volcanoes in Japan, Italy and Chile where the variations in $\mathrm{H}_{2} \mathrm{O}, \mathrm{CO}_{2}$ and $\mathrm{SO}_{2}$ have been successfully investigated (Shinohara et al., 2003; Aiuppa et al., 2005, 2006, 2007b; Shinohara and Witter, 2005). In order to use the Multi-GAS data to determine the ratios of the various species in the fumarole gases, plots were constructed to look for correlations between species after they had been corrected for interferences. If necessary, the data was time shifted to best align peaks in concentrations to correct for differences in sensor response times. Examples of these plots are shown in Fig. 2. Only where a correlation significant at the $95 \%$ level was seen are ratios quoted. The values in Table 1 represent measurements at 100-1000 time points; uncertainties quoted for the ratios are based on minimum and maximum slopes through the data points. Measurements were . made around a number of fumaroles at Tatun, and downwind from
Table 1

Molar ratios measured in gases using Multi-GAS and Giggenbach bottles at hydrothermal sites GZP and DYK in the Tatun volcanic group

\begin{tabular}{|c|c|c|c|c|c|c|}
\hline & $\begin{array}{l}\mathrm{H}_{2} \mathrm{O} / \\
\left(\mathrm{S}_{\text {total }}\right)\end{array}$ & $\begin{array}{l}\mathrm{CO}_{2} / \\
\left(\mathrm{S}_{\text {total }}\right)\end{array}$ & $\begin{array}{l}\mathrm{CO}_{2} / \\
\mathrm{H}_{2} \mathrm{~S}\end{array}$ & $\begin{array}{l}\mathrm{SO}_{2} / \\
\mathrm{H}_{2} \mathrm{~S}\end{array}$ & $\begin{array}{l}\mathrm{HCl} / \\
\left(\mathrm{S}_{\text {total }}\right)\end{array}$ & $\begin{array}{l}\mathrm{CO}_{2} / \\
\mathrm{HCl}\end{array}$ \\
\hline GZP A (Giggenbach) & 346.6 & 7.15 & 7.15 & $*$ & 0.01 & 1073 \\
\hline $\begin{array}{l}\text { GZP fumarole A } \\
\text { (Multi-GAS via tube) }\end{array}$ & $127 \pm 25$ & $7.8 \pm 1.3$ & $7.8 \pm 1.3$ & - & & \\
\hline $\begin{array}{l}\text { GZP fumarole A } \\
\text { (Multi-GAS in plume) }\end{array}$ & $82.8 \pm 45$ & $8.4 \pm 1.8$ & $8.5 \pm 1.8$ & - & & \\
\hline GZP fumarole B (Multi-GAS) & - & $8.7 \pm 3$ & $8.7 \pm 3$ & - & & \\
\hline $\begin{array}{l}\text { GZP bubbling mud } \\
\text { (Multi-GAS) }\end{array}$ & $176 \pm 41$ & $11.6 \pm 1.4$ & $11.8 \pm 1.5$ & - & & \\
\hline DYK C (Giggenbach) & 328.8 & 3.30 & 8.57 & 1.60 & 0.20 & 16.6 \\
\hline $\begin{array}{l}\text { DYK upwind of fumarole C } \\
\text { (Multi-GAS) }\end{array}$ & - & $13.1 \pm 1.5$ & $24.6 \pm 7.1$ & $0.89 \pm 0.2$ & & \\
\hline DYK D (Giggenbach) & 633 & 16.6 & 37.8 & 1.27 & 0.73 & 22.8 \\
\hline DYK fumarole D (Multi-GAS) & - & $16.4 \pm 4.4$ & $37.7 \pm 19$ & $1.44 \pm 0.3$ & & \\
\hline
\end{tabular}

Where there was no clear correlation observed between species a dash is shown. $* \mathrm{SO}_{2}$ was below detection in the GZP Giggenbach sample.

their emission points. Spikes in real-time measurements of $\mathrm{H}_{2} \mathrm{~S}, \mathrm{CO}_{2}$, humidity and temperature were detected in these plumes. Measurements of mercury in the gases of the fumaroles revealed concentrations elevated above background levels. During the measurements, Giggenbach samples were collected at DYK C and D as well as GZP A.

\subsection{Multi-GAS measurements at Geng-tze-ping (GZP)}

Measurements were made at a fumarole (A) at GZP by passing gas from the titanium and Tygon sampling tube used for Giggenbach sampling straight into the inlet of the Multi-GAS sensor (Fig. 3) to try to minimize the dilution of the gas with background air before sampling. Measurements were also made with the inlet of the instrument in the plume of the fumarole gases. The concentrations of species measured in the gas plume and via the sampling tube at this fumarole are similar, despite the probable changes in the proportion of background air sampled (Fig. 4a). During this sampling period $\mathrm{SO}_{2}$ was at or below the detection limit of the sensor $(0.4 \mathrm{ppm})$ in the GZP gases. $\mathrm{H}_{2} \mathrm{~S}, \mathrm{H}_{2} \mathrm{O}$ and $\mathrm{CO}_{2}$ concentrations all correlate well during sampling at this fumarole.

With the exception of $\mathrm{H}_{2} \mathrm{O}$, the ratios of the species to total $\mathrm{S}$ in the gases were similar when sampling with or without the titanium/ Tygon sampling tube (Table 1 ) and peak humidity values and peak concentrations of $\mathrm{H}_{2} \mathrm{~S}$ and $\mathrm{CO}_{2}$ were of a similar magnitude in the plume and when measured via the titanium/Tygon tube.

Other sites within the GZP area were also studied with the MultiGAS. Fumarole B (Fig. 3), is a small fumarole which was gently releasing gases. Higher concentrations of gases were recorded during sampling at this fumarole than were recorded at fumarole GZP A (Fig. 4, Table 3), however, ratios observed in the gases of the GZP fumaroles were similar (Section 3.4). Measurements at a bubbling mud pool at GZP were also made (Fig. 3). At this location elevated concentrations of $\mathrm{H}_{2} \mathrm{~S}$ (9 ppm)
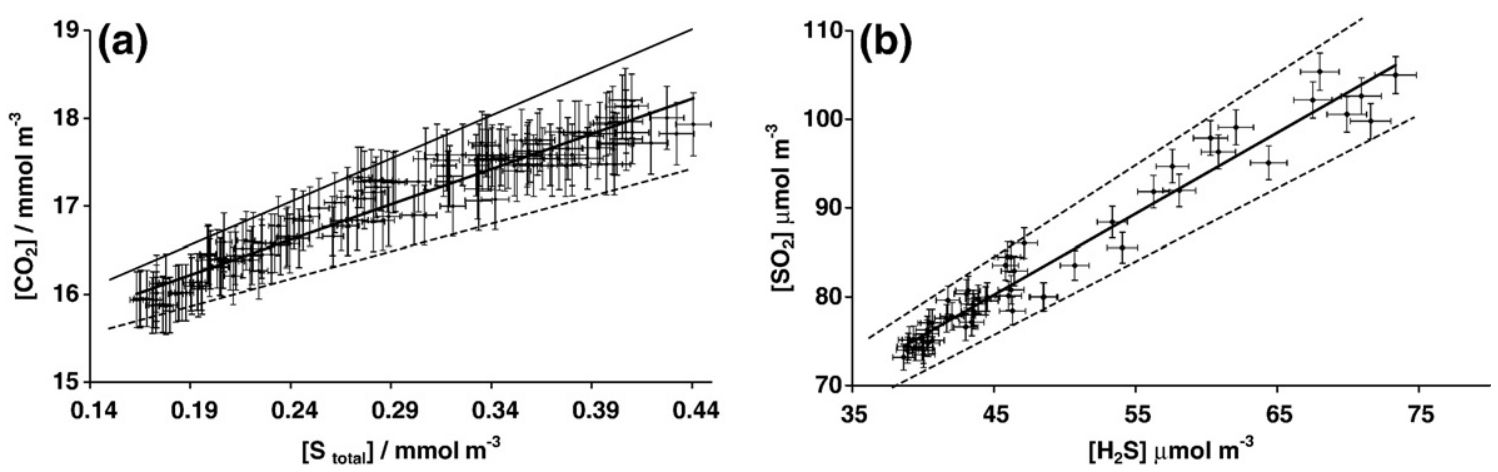

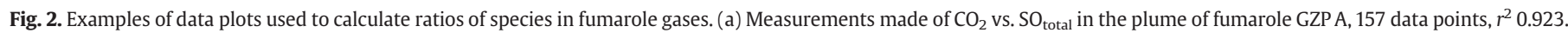
(b) Measurements made of $\mathrm{H}_{2} \mathrm{~S}$ vs. $\mathrm{SO}_{2}$ in the plume of fumarole DYK C, 55 data points, $r^{2}$ 0.952. 

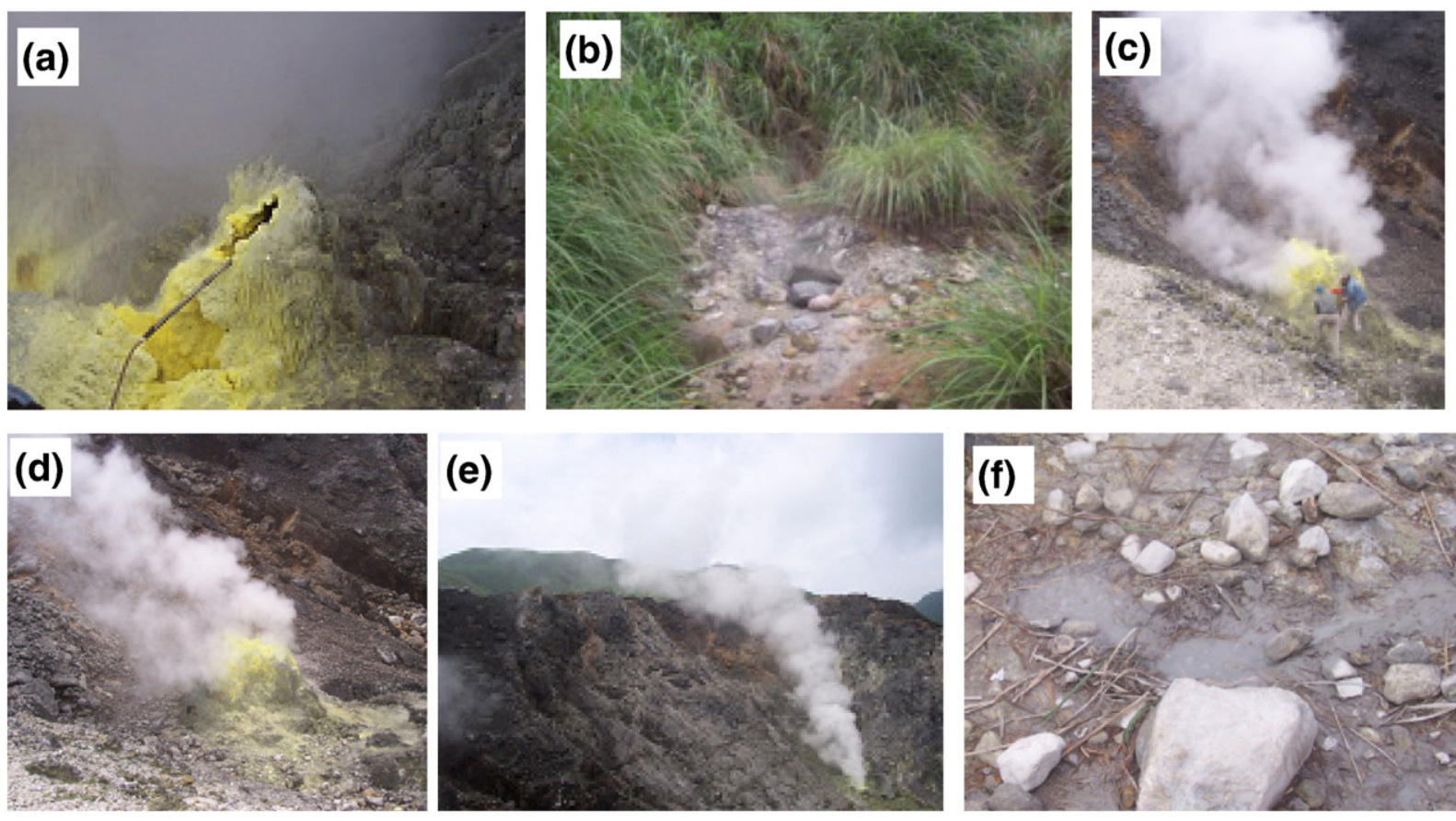

(e)
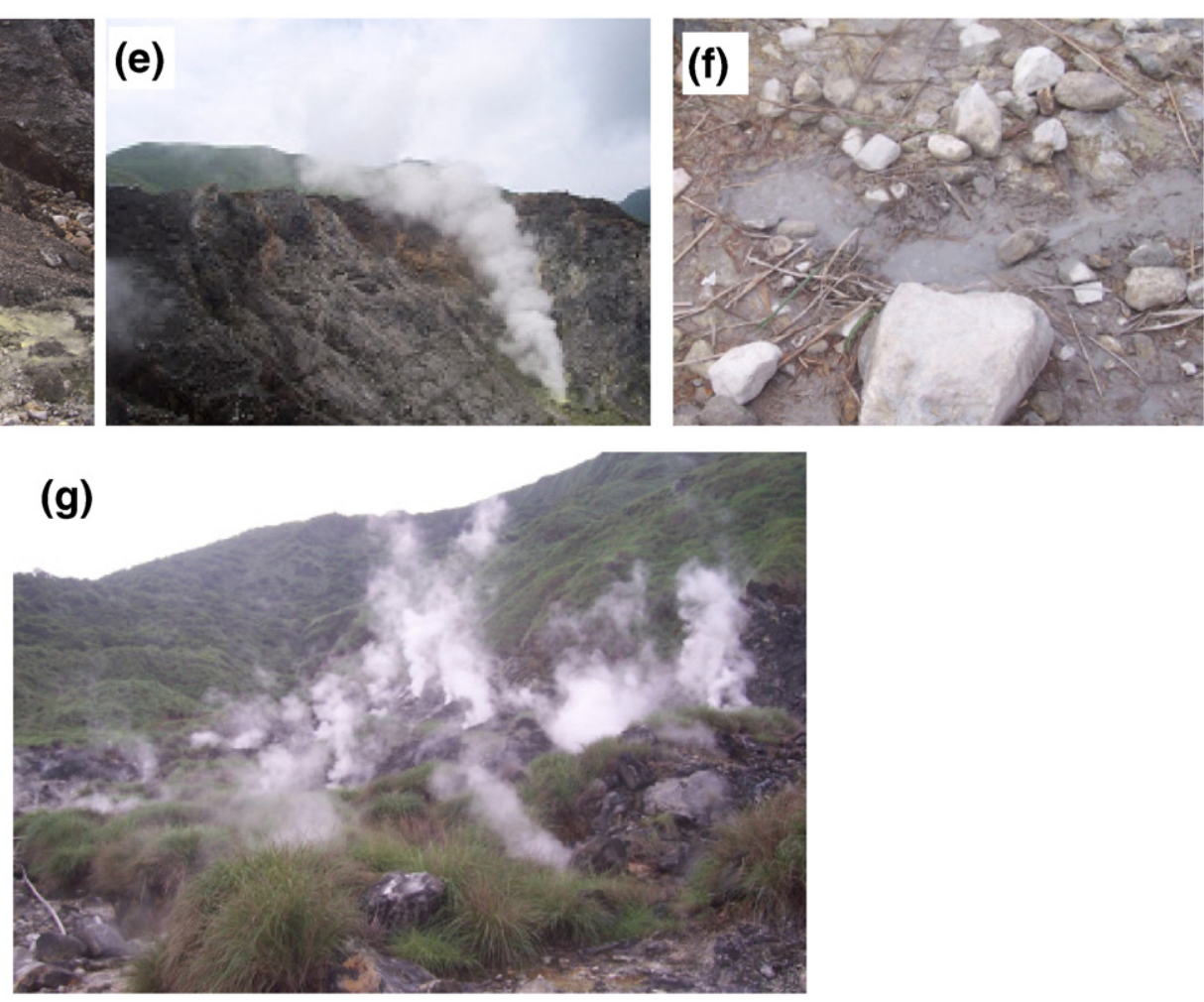

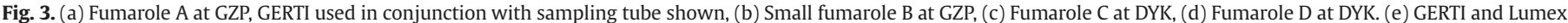

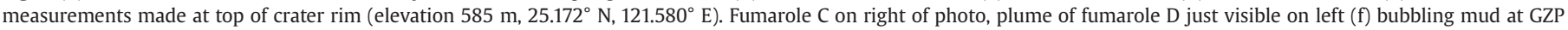
(g) fumaroles at GZP.

and $\mathrm{CO}_{2}(540 \mathrm{ppm})$ were also observed. The $\mathrm{CO}_{2} / \mathrm{S}_{\text {total }}$ ratios were slightly higher than those recorded at the fumaroles in the area.

\subsection{Multi-GAS measurements at Da-you-keng (DYK)}

The temperatures measured at the fumaroles at DYK were around $116{ }^{\circ} \mathrm{C}$. This is higher than measurements made here 2 years ago which were around $100{ }^{\circ} \mathrm{C}$ (Lee et al., 2005). A similar range in concentrations was observed at fumaroles $C$ and D with the MultiGAS at DYK. This is perhaps an unexpected result as the measurements were made at a distance of $10-20 \mathrm{~m}$ from fumarole $C$ whereas measurements were made adjacent to fumarole $D$. The fumarole $C$ did appear to have a smaller plume than fumarole D and measurements at both locations may have been influenced by variations in the amount of dilution with background air as wind patterns changed on a short timescale.

\subsection{Giggenbach flask sampling at Tatun}

Giggenbach samples were collected at fumarole A at GZP and at fumaroles $C$ and $D$ at DYK. A number of species were determined in these samples and their concentrations are reported in Table 2. As for the Multi-GAS, $\mathrm{SO}_{2}$ was not detected in the fumarole gases at GZP while a signal was observed at DYK. In previous work, Lee et al. (2005) found that DYK had the highest concentration of $\mathrm{SO}_{2}$ of all of the sites studied around Tatun and recorded a $\mathrm{SO}_{2} / \mathrm{H}_{2} \mathrm{~S}$ ratio of 0.18 in 2003 in Giggenbach samples collected here. The $\mathrm{SO}_{2} / \mathrm{H}_{2} \mathrm{~S}$ ratios reported for DYK in Table 2 are higher than this ratio. Subsequent work by Lee et al. (2008-this issue) investigating temporal variations over 3 years at Tatun suggested an increasing $\mathrm{SO}_{2} / \mathrm{H}_{2} \mathrm{~S}$ ratio in the sampling period.

\section{4. $\mathrm{CO}_{2} / \mathrm{S}$ ratios recorded with Multi-GAS and Giggenbach sampling}

The Multi-GAS $\mathrm{CO}_{2} / \mathrm{S}$ ratio measured via the titanium/Tygon sampling tube at GZP A was about 10\% higher than observed with the Giggenbach techniques. Shinohara (2005) also found $\mathrm{CO}_{2} / \mathrm{SO}_{2}$ ratios in Giggenbach samples at a fumarole at Tokachi volcano agreed with Multi-GAS results to within $10 \%$. The Multi-GAS $\mathrm{CO}_{2} / \mathrm{S}$ ratios in the plume of GZP A and GZP B were higher than when sampling via the tube. The highest $\mathrm{CO}_{2} / \mathrm{S}$ ratio was recorded at the bubbling mud pool at GZP. All of the $\mathrm{CO}_{2} / \mathrm{S}$ ratios at GZP were of a similar magnitude with a variation of less than $10 \%$ between all of the $\mathrm{CO}_{2} / \mathrm{S}$ ratios at GZP A and GZP B measured by the techniques. 
(a)
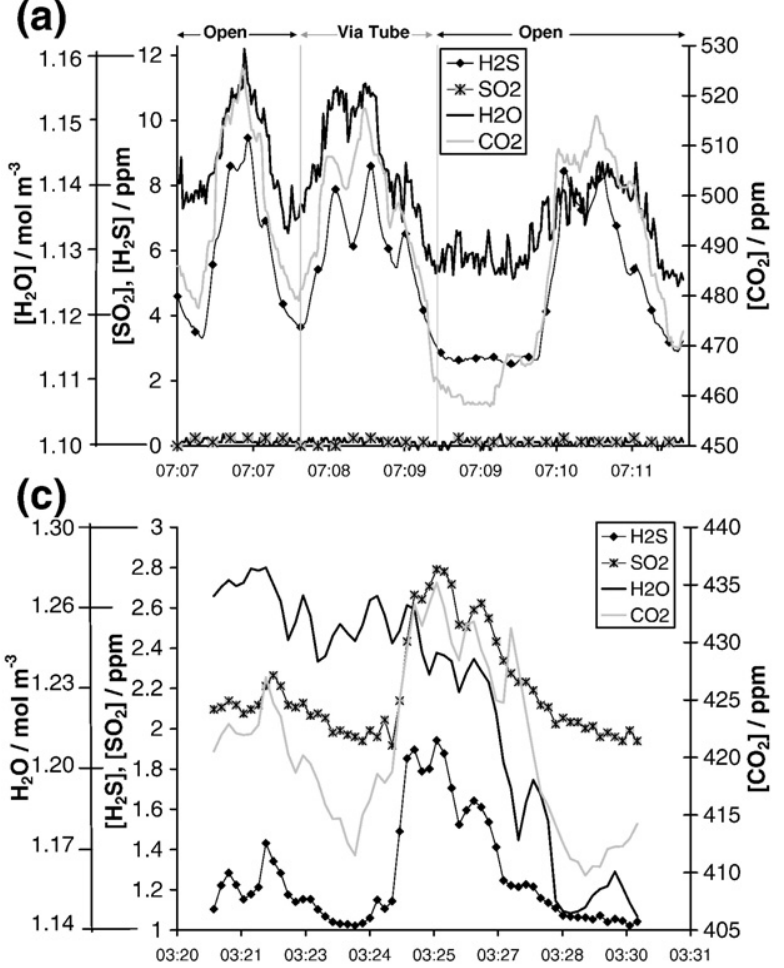

(b)

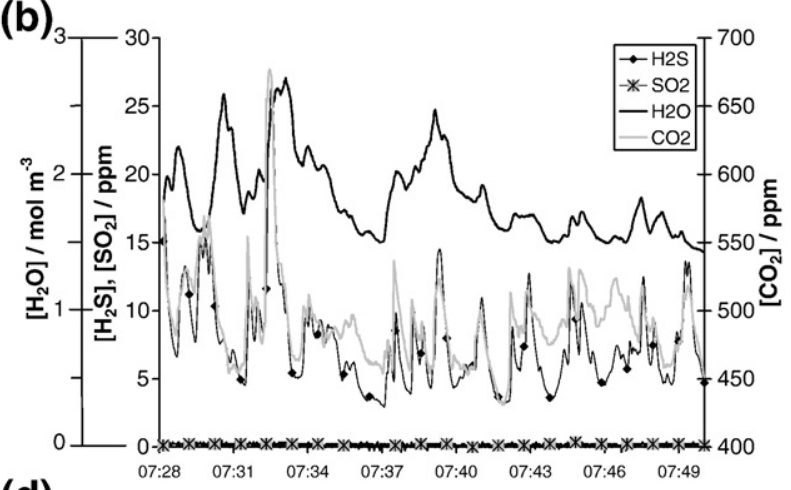

(d)

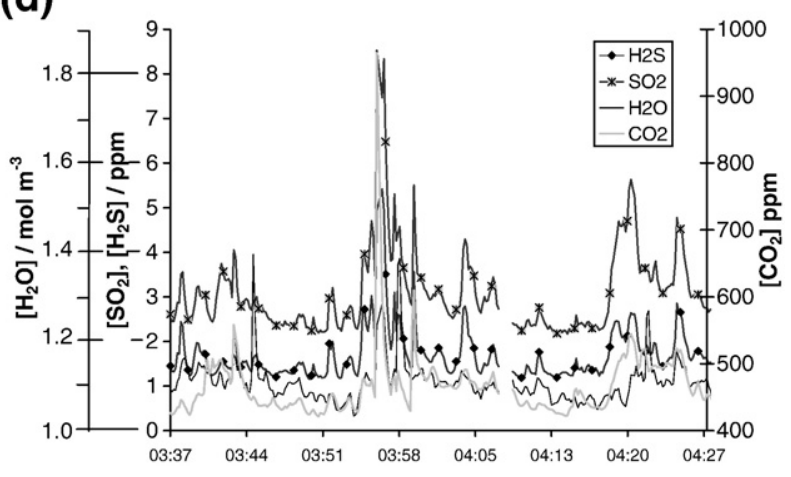

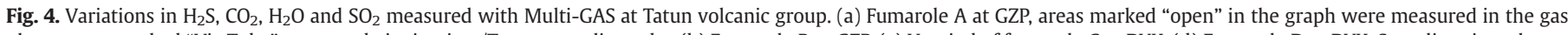

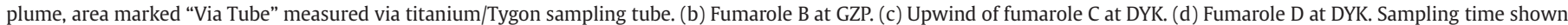
along $x$-axis in UTC, local time is UTC +8 .

A similar result was found at the fumaroles at DYK, where sampling was made closest to the fumarole at DYK D, the $\mathrm{CO}_{2} / \mathrm{S}$ ratios recorded by the Giggenbach method and with the Multi-GAS showed around 1\% difference. At DYK C, where the Multi-GAS was 10-20 m from the fumarole the Multi-GAS $\mathrm{CO}_{2} / \mathrm{S}$ ratio was approximately 4 times higher than the Giggenbach value.

\section{5. $\mathrm{H}_{2} \mathrm{O} / \mathrm{S}$ and $\mathrm{H}_{2} \mathrm{~S} / \mathrm{SO}_{2}$ ratios recorded with Multi-GAS and Giggenbach sampling}

Other molar ratios investigated with the Multi-GAS and Giggenbach sampling methods showed a greater variation than the $\mathrm{CO}_{2} / \mathrm{S}$ ratios. The $\mathrm{SO}_{2} / \mathrm{H}_{2} \mathrm{~S}$ ratios at DYK were all of the same order of magnitude (geometric mean based on all measurements of $\mathrm{SO}_{2} / \mathrm{H}_{2} \mathrm{~S}$ 1.4). At DYK D Multi-GAS measurements were made closer to the fumarole and the $\mathrm{S}$ ratios of the techniques showed less than $10 \%$ variation. At DYK C, where the Multi-GAS measurements were made at a distance from the fumarole, a greater difference between the Giggenbach and Multi-GAS SO $\mathrm{S}_{2} / \mathrm{H}_{2} \mathrm{~S}$ ratios were observed (43\%).

The $\mathrm{H}_{2} \mathrm{O} /\left(\mathrm{H}_{2} \mathrm{~S}+\mathrm{SO}_{2}\right)$ ratios measured by the two techniques showed a most variability between techniques. The humidity data from DYK did not show a significant correlation with the other species simultaneously monitored and so this data could not be compared to the Giggenbach results. The Multi-GAS values for the water content of the plume are based on the relative humidity and temperatures recorded, as the fumarolic gas is probably supersaturated with $\mathrm{H}_{2} \mathrm{O}$, water vapour is visible at the vent, and the humidity sensor will not detect water droplets. This could lead to a poor correlation between humidity data and variation in other species. A correlation was observed between the humidity data and the $\mathrm{S}$ species on only two occasions, at GZP A and at the bubbling mud at GZP. The Multi-GAS $\mathrm{H}_{2} \mathrm{O} / \mathrm{S}$ ratio at GZPA was around 3 to 4 times lower than seen in the Giggenbach samples. The poor agreement in the $\mathrm{H}_{2} \mathrm{O} / \mathrm{S}$ ratio between these techniques and the lack of correlation between the humidity and other species at other sites suggests further work is required before the humidity data can be used to obtain reliable estimates for water content in the gases.

\subsection{Mercury at Tatun}

The mercury analyser monitored the concentration of gaseous elemental mercury (GEM) and reports values as 10 second averages. The mean and range of concentrations measured in the fumaroles are listed in Table 3. A similar mean Hg concentration was observed in the fumarole plumes of A, C and D of around $20 \mathrm{ng} \mathrm{m}^{-3}$. This is an order of magnitude greater than concentrations found in background air at clean air locations ( $\sim 2 \mathrm{ng} \mathrm{m}^{-3}$, e.g. Ebinghaus et al., 2002) and significantly higher than reported from both rural $\left(6 \mathrm{ng} \mathrm{m}^{-3}\right)$ and urban/industrial sites (8-9 $\mathrm{ng} \mathrm{m}^{-3}$ ) elsewhere in northern Taiwan (Kuo et al., 2006).

At GZP, measurements were made with the sample inlet several centimeters above the ground and at about 1-1.5 m above the ground. Gustin et al. (1996) found that mercury concentrations above mercury enriched ground decreased exponentially with height and that the mercury flux rose by 1-2 orders of magnitude on exposure to incident light. When the sample inlets were placed close to the ground, mercury

Table 2

Measurements made with Giggenbach bottles 29th and 30th April 2007

\begin{tabular}{|c|c|c|c|c|c|c|c|c|c|c|c|c|c|c|c|}
\hline & $\mathrm{T}\left({ }^{\circ} \mathrm{C}\right)$ & $\mathrm{H}_{2} \mathrm{O}$ & $\mathrm{CO}_{2}$ & $\mathrm{~S}_{\text {Total }}$ & $\mathrm{SO}_{2}$ & $\mathrm{H}_{2} \mathrm{~S}$ & $\mathrm{HCl}$ & $\mathrm{Ar}$ & $\mathrm{O}_{2}$ & $\mathrm{~N}_{2}$ & $\mathrm{CH}_{4}$ & $\mathrm{H}_{2}$ & $\mathrm{HF}$ & $\mathrm{He}$ & $\mathrm{CO}$ \\
\hline$\overline{\text { GZP A }}$ & 110 & 96,779 & 1996 & 279 & 0 & 278 & 1.86 & 0.097 & 0.030 & 33.3 & 2.188 & 0.022 & 0.124 & 0.040 & 0.00289 \\
\hline DYK C & 116 & 98,247 & 986 & 299 & 184 & 115 & 59.3 & 0.155 & 0.228 & 21.5 & 0.416 & 0.584 & 0.065 & 0.024 & 0.00067 \\
\hline DYK D & 112 & 96,849 & 2531 & 153 & 85.3 & 67.2 & 111.2 & 1.278 & 24.13 & 105.0 & 0.351 & 0.016 & 0.258 & 0.028 & 0.00125 \\
\hline
\end{tabular}

Units (1000x) mol\% of total gas. Column T shows fumarole temperature in ${ }^{\circ} \mathrm{C}$. 
Table 3

Concentrations measured in fumarole gases at GZP and DYK, Tatun, using Multi-GAS and a portable mercury analyser

\begin{tabular}{|c|c|c|c|c|c|}
\hline & 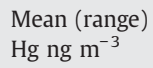 & $\begin{array}{l}\text { Mean (range) } \\
\mathrm{S}_{\text {tot }} \mathrm{mmol} \mathrm{m}^{-3}\end{array}$ & $\begin{array}{l}\text { Mean (range) } \\
\mathrm{CO}_{2} \mathrm{mmol} \mathrm{m}^{-3}\end{array}$ & $\begin{array}{l}\mathrm{Hg} / \mathrm{CO}_{2} \\
\text { molar (mass) }\end{array}$ & $\begin{array}{l}\mathrm{Hg} / \mathrm{S}_{\text {tot }} \\
\text { molar (mass) }\end{array}$ \\
\hline $\begin{array}{l}\text { GZP A } \\
\text { plume }\end{array}$ & $\begin{array}{l}23.2 \\
(3.9-104)\end{array}$ & $\begin{array}{l}0.270 \\
(0.199-0.388)\end{array}$ & $\begin{array}{l}19.6 \\
(17.3-24.3)\end{array}$ & - & - \\
\hline $\begin{array}{l}\text { GZP A } \\
\text { close to } \\
\text { ground }\end{array}$ & $\begin{array}{l}291.5 \\
(12.7-696)\end{array}$ & $\begin{array}{l}0.141 \\
(0.067-0.307)\end{array}$ & $\begin{array}{l}18.0 \\
(14.7-39.0)\end{array}$ & - & - \\
\hline $\begin{array}{l}\text { GZP B } \\
\text { plume }\end{array}$ & $\begin{array}{l}5.45 \\
(2.2-16.9)\end{array}$ & $\begin{array}{l}0.132 \\
(0.112-0.179)\end{array}$ & $\begin{array}{l}13.9 \\
(13.5-14.5)\end{array}$ & $\begin{array}{l}9.8 \pm 5.5 \times 10^{-9} \\
\left(4.5 \pm 2.8 \times 10^{-8}\right)\end{array}$ & - \\
\hline $\begin{array}{l}\text { DYK C } \\
\text { plume }\end{array}$ & $\begin{array}{l}18.9 \\
(9.0-28.3)\end{array}$ & $\begin{array}{l}0.127 \\
(0.082-0.316)\end{array}$ & $\begin{array}{l}15.4 \\
(13.9-21.3)\end{array}$ & $\begin{array}{l}8.5 \pm 0.3 \times 10^{-8} \\
\left(3.9 \pm 0.1 \times 10^{-7}\right)\end{array}$ & $\begin{array}{l}1.2 \pm 0.3 \times 10^{-6} \\
\left(5.0 \pm 0.9 \times 10^{-6}\right)\end{array}$ \\
\hline $\begin{array}{l}\text { DYK D } \\
\text { plume }\end{array}$ & $\begin{array}{l}19.7 \\
(3.9-66.3)\end{array}$ & $\begin{array}{l}0.117 \\
(0.095-0.163)\end{array}$ & $\begin{array}{l}16.0 \\
(15.5-16.9)\end{array}$ & $\begin{array}{l}3.5 \pm 0.2 \times 10^{-8} \\
\left(1.6 \pm 0.7 \times 10^{-7}\right)\end{array}$ & $\begin{array}{l}9.7 \pm 1.8 \times 10^{-7} \\
\left(2.4 \pm 0.9 \times 10^{-6}\right)\end{array}$ \\
\hline $\begin{array}{l}\text { DYK D } \\
\text { close to } \\
\text { ground }\end{array}$ & $\begin{array}{l}129.8 \\
(22.9-219)\end{array}$ & $\begin{array}{l}0.337 \\
(0.243-0.546)\end{array}$ & $\begin{array}{l}17.8 \\
(16.3-20.0)\end{array}$ & - & - \\
\hline
\end{tabular}

$\mathrm{Hg} / \mathrm{CO}_{2}$ and $\mathrm{Hg} / \mathrm{S}_{\text {tot }}$ ratios are molar ratios (mass ratio in brackets below) based on the best line fit of Multi-GAS and Lumex measurements. Where there was no clear correlation observed between species a dash is shown.

concentrations rose sharply, concentrations up to $\sim 700 \mathrm{ng} \mathrm{m}^{-3}$ were recorded close to the ground. A similar observation was made at DYK where GEM concentrations rose sharply when the instrument inlet was placed close to the ground from $19.7 \pm 9.3 \mathrm{ng} \mathrm{m}^{-3}$ to $130 \pm 42 \mathrm{ng} \mathrm{m}^{-3}$. The peaks in GEM recorded close to the ground at GZP coincided with periods when the sun broke through the clouds at the site, and did not always correspond to the occurrence of $\mathrm{CO}_{2}$ or $\mathrm{H}_{2} \mathrm{~S}$ peaks; this dependence of mercury evasion on solar radiation flux is well known (e.g. Poissant and Casimir, 1998; García-Sánchez et al., 2006). Revolatilization of $\mathrm{Hg}$ from soils and surfaces is an established source of $\mathrm{Hg}$ to the atmosphere (Poissant and Casimir, 1998). In addition to volatilization from soil surfaces, mercury may be released through the soil flux in a similar manner to the release of $\mathrm{CO}_{2}$. Although gases released through the soil in volcanic regions may have a similar origin to those released at fumaroles, the composition may vary due to differences in the interactions prior to release. In studies at the Tatun site Liu-Huang-Ku the composition of the soil gas was found to be similar to that of the fumaroles gases for a number of species (Lan et al., 2007). The scatter in the $\mathrm{Hg}$ to $\mathrm{CO}_{2}$ and $\mathrm{S}$ data plots at some locations suggests gases sampled originated from a mixture of these three gas release mechanisms.

The high GEM concentrations observed in the vicinity of the fumaroles which did not correlate with other volcanic gases, suggest there are high levels of mercury on the ground surface in the area. This mercury is presumably deposited from the continuous $\mathrm{Hg}$ emissions of the fumaroles and remobilised by a variety of processes in the presence of water, heat and sunlight (e.g. Landa, 1978; Lindberg et al., 1999; Gustin et al., 2000). Similar features have been reported from hydrothermal systems elsewhere (Engle et al., 2006), but much further work is needed to understand and quantify the controls on the rates of mercury deposition and evasion around active fumaroles.

\subsection{Molar ratios in Tatun gases}

Measurements made at fumarole A, may show the changing chemistry of the fumarolic gases as they mix with background air. The measurements based on analysis of the Giggenbach flask should show the smallest influence of background air (1), the Multi-GAS measurements made via the titanium/Tygon tube may be considered intermediate (2), while the most mixing was expected when measuring the fumarole plume (3). The $\mathrm{CO}_{2} / \mathrm{H}_{2} \mathrm{~S}$ ratios measured increased with greater mixing and were (1) 7.18, (2) 7.81 and (3) 8.42. A similar result was observed at DYK; measurements made at fumarole $\mathrm{C}$ with a Giggenbach flask yielded a $\mathrm{CO}_{2} / \mathrm{H}_{2} \mathrm{~S}$ ratio of 8.6, whereas measurements made with the Multi-GAS at the crater rim, several meters downwind of the fumarole, resulted in a $\mathrm{CO}_{2} / \mathrm{H}_{2} \mathrm{~S}$ ratio of 24.6. This rise in $\mathrm{CO}_{2} / \mathrm{H}_{2} \mathrm{~S}$ ratio may suggest a rapid oxidation of the $\mathrm{H}_{2} \mathrm{~S}$ on mixing with background air. However this rise in $\mathrm{CO}_{2} / \mathrm{H}_{2} \mathrm{~S}$ is not accompanied by a corresponding rise in $\mathrm{SO}_{2}$ in the samples. Another possibility could be an additional source of $\mathrm{CO}_{2}$ from soil degassing. If the $\mathrm{CO}_{2} / \mathrm{H}_{2} \mathrm{~S}$ ratio from soil is higher than in the fumarole gas this could also lead to such a rise. Also contributing to a higher $\mathrm{CO}_{2} / \mathrm{H}_{2} \mathrm{~S}$ ratio could be the increased dilution of volcanic gases with background air.

The ratios measured at the fumaroles with the Multi-GAS show some variations over time. Some of this variability may have been due to instrumental effects as the various sensors have differing response times to the analytes. This makes it difficult to establish if the changes in molar ratios observed over short time periods are artefacts or genuine changes in chemistry. The ratios reported in Table 1 are based on the correlation between the various species over the entire sampling period, and as such offer a ratio based on a large number of data points, increasing the confidence in the values.

Plots of GEM concentrations against $\mathrm{CO}_{2}$ and $\mathrm{S}_{\text {total }}$ were used to determine molar ratios at the fumaroles (Fig. 5, Table 3 ). $\mathrm{Hg} / \mathrm{CO}_{2}$ ratios
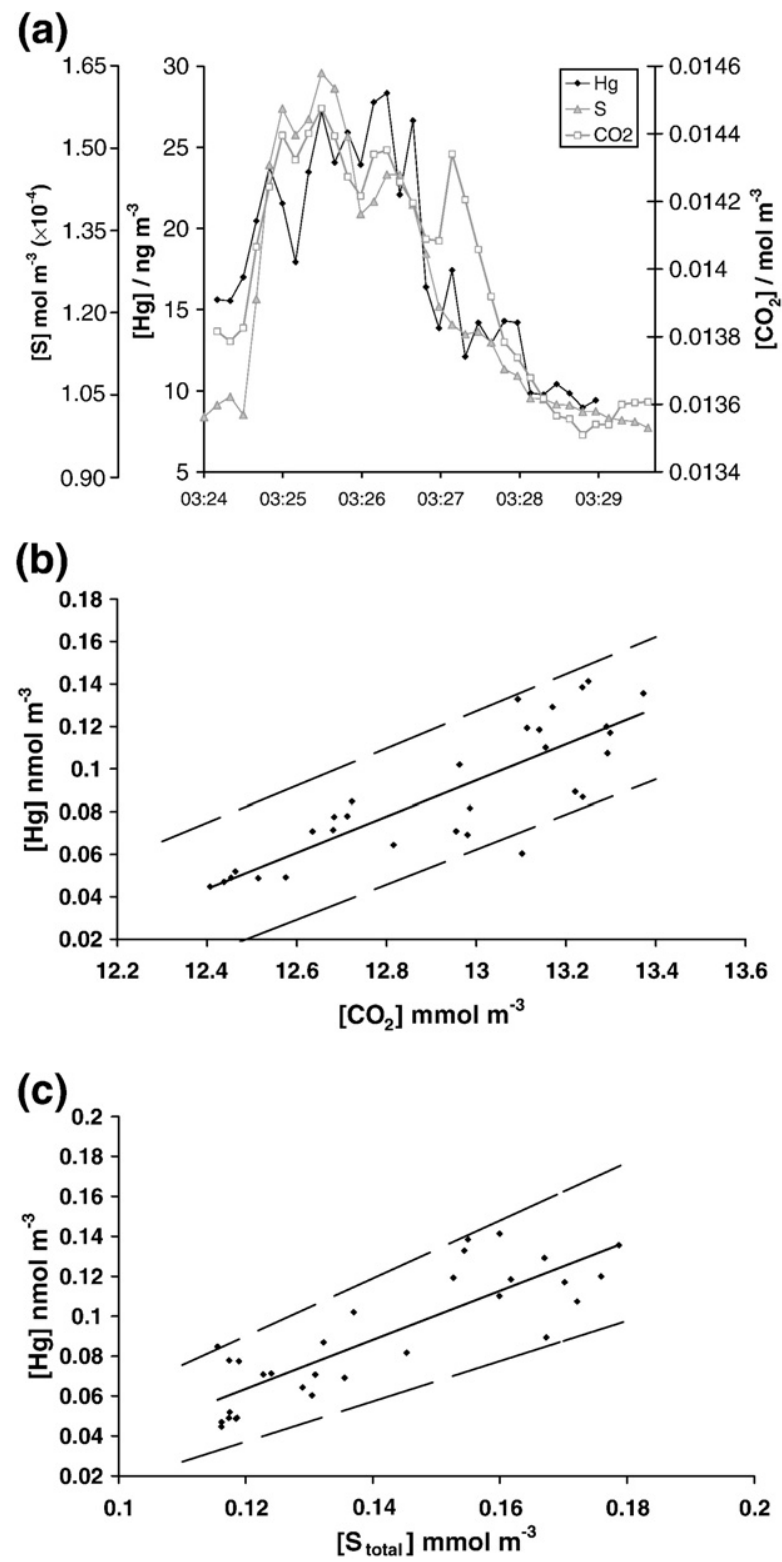

Fig. 5. GEM, $\mathrm{S}$ and $\mathrm{CO}_{2}$ concentrations measured at fumarole DYKC, Tatun. (a) Variations in GEM, $\mathrm{CO}_{2}$ and $\mathrm{S}$ over time, (b) GEM vs. $\mathrm{CO}_{2}$ (c) GEM vs. S. Data points represent 10 second averages based on measurements made every second. 
from the plumes measured at the DYK fumaroles suggest a molar ratio of $\sim 4-9 \times 10^{-8}$. This is similar to results using these same instruments from low-temperature steam-dominated fumaroles near Masaya volcano (molar $\mathrm{Hg} / \mathrm{CO}_{2} \sim 0.4 \times 10^{-8}$; (; Witt et al., in press), and in fumaroles at Vulcano, Italy (molar $\mathrm{Hg} / \mathrm{CO}_{2} \sim 10^{-8}$; Aiuppa et al., 2007a). These values are significantly higher than the clean, background atmosphere $\left(\sim 5 \times 10^{-10}\right)$, and emphasise the potential significance of fumarole emissions for regional atmospheric mercury budgets.

Prior estimates of the global flux of $\mathrm{Hg}$ from fumarole systems have used the scaling relationships between heat flux and gas emissions (e.g. Varekamp and Buseck, 1986; Engle et al., 2006). For the Tatun field, there are not yet sufficient data on $\mathrm{CO}_{2}$ and thermal fluxes for us to make a rigorous assessment of the total net $\mathrm{Hg}$ flux using geostatistical techniques (c.f. Engle et al., 2006). However, Lan et al. (2007) recently measured the soil $\mathrm{CO}_{2}$ emission rate from the nearby Liu-Huang $\mathrm{Ku}$ (LHK) hydrothermal area as $\sim 20 \mathrm{Mg} /$ day (580-660 $\mathrm{Mg} \mathrm{km}^{-2}$ day $^{-1}$ ). While the emissions measured in the fumaroles gases may differ to some extent to the composition of the soil gas, they represent the best estimate available to obtain the $\mathrm{Hg}$ emission flux at present. Assuming a molar $\mathrm{Hg} / \mathrm{CO}_{2} \sim 5 \times 10^{-8}$, and assuming, conservatively, that the soil $\mathrm{CO}_{2}$ fluxes from other two main hydrothermally-altered areas of the Tatun field (Fig. 1) are of the same order of magnitude as LHK, this gives a daily $\mathrm{CO}_{2}$ flux of $60-600 \mathrm{Mg}$, and a total annual $\mathrm{Hg}$ flux of $\sim 5-50 \mathrm{~kg} /$ year. This value approaches the order of magnitude of total annual $\mathrm{Hg}$ emissions from Vulcano (4-7 kg Hg/yr; Aiuppa et al., 2007a) or Yellowstone (15-50 kg Hg/yr; Engle et al., 2006).

$\mathrm{The} \mathrm{Hg} / \mathrm{S}$ ratios were also investigated in the fumarole gases. At GZP, where $\mathrm{S}$ is predominantly present as $\mathrm{H}_{2} \mathrm{~S}$, no good correlation was observed between total $\mathrm{S}$ and gaseous elemental mercury concentrations. This may reflect variable scrubbing of $S$ species in the hydrothermal system. At DYK, gaseous elemental mercury and $S_{\text {total }}$ signal were correlated, with a molar $\mathrm{Hg} / \mathrm{S}$ ratio of $0.7-1.2 \times 10^{-6}$.

Measurements at Tatun show that the system is releasing mercury at levels elevated well above those of the background. While much of the GEM emitted at Tatun is likely to be transported to great distances prior to deposition, the elevated levels of mercury measured close to the ground near the fumaroles suggest that deposition from the high concentration plume to the ground is locally important. Studies of the speciation of mercury in volcanic and fumarolic gases have found significant levels of particulate and reactive gaseous mercury to be present (e.g. 1-2\% $\mathrm{Hg}$ as RGM in Yellowstone; $1 \% \mathrm{Hg}$ as $\mathrm{Hg}_{\mathrm{p}}$ in hightemperature emissions from Etna; Bagnato et al., 2007; Engle et al., 2006). These forms of mercury will be readily removed from the atmosphere, particularly in a steam-saturated, condensing plume, potentially enhancing local $\mathrm{Hg}$ deposition fluxes.

\section{Conclusions}

We performed the first measurements of gas species at Tatun volcano with a Multi-GAS analyser and portable mercury spectrometer. The data obtained allowed for the comparison of abundance ratios measured by sensors to the results obtained simultaneously from direct fumarole sampling using Giggenbach flasks. The comparison of the results obtained by both techniques shows that a) there is good agreement of some abundance ratios $\left(\mathrm{CO}_{2} /\left(\mathrm{H}_{2} \mathrm{~S}+\mathrm{SO}_{2}\right)\right)$; b) water contents measured in situ are consistently lower than in the gas samples this is likely due to supersaturation of the air with steam and the formation of water droplets which are not detected by the sensors; and c) increased mixing with air and resulting oxidation of $\mathrm{H}_{2} \mathrm{~S}$ to $\mathrm{SO}_{2}$ is a likely explanation for the observed variations of $\mathrm{CO}_{2} /\left(\mathrm{H}_{2} \mathrm{~S}-\mathrm{SO}_{2}\right)$ ratios at some localities. Further and systematic comparison of sensors and direct sampling techniques is critical for better understanding volcanic degassing and the evolution of gases as they mix with air.

Mercury concentrations in the fumarole gases were elevated above levels observed in urban/industrial areas of northern Taiwan. High
GEM concentrations observed when the sample inlet was lowered suggest that the ground surface surrounding the fumaroles is enriched in mercury. $\mathrm{Hg} / \mathrm{CO}_{2}$ ratios measured in the fumarole gases at DYK and GZP were comparable to those of similar low-temperature systems at other locations, and combined with a local soil flux estimate suggest an annual $\mathrm{Hg}$ flux of 5-50 kg/year from the Tatun field.

\section{Acknowledgements}

The authors thank Tefang Faith Lan, Hsiao-Fen Lee of National Taiwan University, Olivier Moreau and Luiza Cioflec of Academia Sinica, Taipei and Evgenia Ilyinskaya, and Rob Martin of Cambridge University for their assistance and advice in the field. We thank Paul Taylor of the University of Cambridge, Department of Earth Sciences for construction of the gas sensor system. This work was funded by NERC grant NE/C511180/1/. The authors thank Alessandro Aiuppa and Hiroshi Shinohara for their thoughtful comments on the manuscript.

\section{References}

Aiuppa, A., Federico, C., Giudice, G., Gurrieri, S., 2005. Chemical mapping of a fumarolic field: La Fossa Crater, Volcano Island (Aeolian Islands, Italy). Geophysical Research Letters 32, L13309.

Aiuppa, A., Federico, C., Giudice, G., Gurrieri, S., Liuzzo, M., Shinohara, H., Favara, R. Valenza, M., 2006. Rates of carbon dioxide plume degassing from Mount Etna volcano. Journal of Geophysical Research: Solid Earth 111, B09207.

Aiuppa, A., Bagnato, E., Witt, M.L.I., Mather, T.A., Parello, F., Pyle, D.M., Martin, R.S 2007a. Real-time simultaneous detection of volcanic $\mathrm{Hg}$ and $\mathrm{SO}_{2}$ at La Fossa Crater Vulcano (Aeolian Islands, Sicily). Geophysical Research Letters 34, L21307. doi:10.1029/2007GL030762.

Aiuppa, A., Moretti, R., Federico, C., Giudice, G., Gurrieri, S., Liuzzo, M., Papale, P., Shinohara, H., Valenza, M., 2007b. Forecasting Etna eruptions by real-time observation of volcanic gas composition. Geology 12 (35), 1115-1118.

Bagnato, E., Aiuppa, A., Parello, F., Calabrese, S., D'Alessandro, W., Mather, T.A McGonigle, A.J.S., Pyle, D.M., Wängberg, I., 2007. Degassing of gaseous (elemental and reactive) and particulate mercury from Mount Etna volcano (Southern Italy). Atmospheric Environment 41, 7377-7388.

Chen, C.H., Wu, Y.J., 1971. Volcanic geology of the Tatun geothermal area, northern Taiwan. Proceedings of the Geological Society of China 14, 5-20.

Chen, C.H., Lin, S.B., 2002. Eruptions younger than 20 ka of the Tatun Volcano Group as viewed from the sediments of the Sungshan Formation in Taipei Basin. Western Pacific Earth Science 2, 191-204.

Chiodini, G., Cioni, R., Marini, L., Panichi, C., 1995. Origin of the fumarolic fluids of Vulcano island, Italy, and implications for volcanic surveillance. Bulletin of Volcanology 57, 99-110.

Chiodini, G., Cioni, R., Guidi, M., Raco, B., Marini, L., 1998. Soil $\mathrm{CO}_{2}$ flux measurements in volcanic and geothermal areas. Applied Geochemistry 13, 543-552.

Ebinghaus, R., Kock, H.H., Coggins, A.M., Spain, T.G., Jennings, S.G., Temme, C., 2002. Long-term measurements of atmospheric mercury at Mace Head, Irish west coast between 1995 and 2001. Atmospheric Environment 36, 5267-5276.

Engle, M.A., Gustin, M.S., Goff, F., Counce, D.A., Janik, C.J., Bergfeld, D., Rytuba, J.J., 2006 Atmospheric mercury emissions from substrates and fumaroles associated with three hydrothermal systems in the western United States. Journal of Geophysical Research 111, D17304. doi:10.1029/2005JD006563.

Ferrara, R., Mazzolai, B., Lanzillotta, E., Nucaro, E., Pirrone, N., 2000. Volcanoes as emission sources of atmospheric mercury in the Mediterranean basin. The Science of the Total Environment 259, 115-121.

Fischer, T.P., Sturchio, N.C., Stix, J., Arehart, G.B., Counce, D., Williams, S.N., 1997. The chemical and isotopic composition of fumarolic gases and spring discharges from Galeras Volcano, Colombia. Journal of Volcanology and Geothermal Research 77 (1-4), 229-253.

Fitzgerald, W.F., Engstrom, D.R., Mason, R.P., Nater, E.A., 1998. The case for atmospheric mercury contamination in remote areas. Environmental Science \& Technology 32 (1), 1-7.

Fulignati, P., Sbrana, A., Clocchiatti, R., Luperini, W., 2006. Environmental impact of the acid fumarolic plume of a passively degassing volcano (Vulcano Island, Italy). Environmental Geology 49, 1139-1155.

García-Sánchez, A., Contreras, F., Adams, M., Santos, F., 2006. Atmospheric mercury emissions from polluted gold mining areas (Venezuela). Environmental Geochemistry and Health 28 (6), 529-540.

Giggenbach, W.F., 1975. A simple method for the collection and analysis of volcanic gas samples. Bulletin of Volcanology 36, 132-145.

Giggenbach, W.F. and Gougel, R., 1989. Method for the collection and analysis of geothermal and volcanic water and gas samples. Chem Div Report no 2387, New Zealand DSIR.

Giggenbach, W.F., 1992. Magma degassing and mineral deposition in hydrotherma systems along convergent plate boundaries. Economic Geology 87, 1927-1944.

Gustin, M.S., Taylor, G.E., Leonard, T.D., Keislar, R.E., 1996. Atmospheric mercury concentrations associated with geologically and anthropogenically enriched sites in central western Nevada. Environmental Science \& Technology 30 (8), 2575-2579. 
Gustin, M.S., Lindberg, S.E., Austin, K., Coolbaugh, M., Vette, A., Zhang, H., 2000. Assessing the contribution of natural sources to regional atmospheric mercury budgets. Science of the Total Environment 259, 61-71.

Hylander, L.D., Meili, M., 2003. 500 years of mercury production: global annual inventory by region until 2000 and associated emissions. Science of the Total Environment 304 (1-3), 13-27.

Kuo, T.H., Chang, C.F., Urba, A., Kvietkus, K., 2006. Atmospheric gaseous mercury in northern Taiwan. Science of the Total Environment 368, 10-18

Lan, T.F., Yang, T.F., Lee, H.-F., Chen, Y.-G., Chen, C.-H., Song, S.-R., Tsao, S., 2007. Compositions and flux of soil gas in Liu-Huang-Ku hydrothermal area, northern Taiwan. Journal of Volcanology and Geothermal Research 165, 32-45.

Landa, E.R., 1978. The retention of metallic mercury vapour by soils. Geochimica et Cosmochimica Acta 42, 1407-1411.

Lee, H.F., Yang, T.F., Lan, T.F., Song, S.R., Tsao, S., 2005. Fumarolic gas composition of the Tatun Volcano Group, northern Taiwan. Terrestrial Atmospheric and Oceanic Sciences 16 (4), 843-864.

Lee, H.F., Yang, T.F., Lan, T.F., Chen, C.H., Song, S.R., Tsao, S., 2008. Temporal variations of gas compositions of fumaroles in the Tatun Volcano Group, northern Taiwan. Journal of Volcanology and Geothermal Research 178 (4), 626-637 (this issue).

Lindberg, S.E., Zhang, H., Gustin, M., Vette, A., Marsik, F., Owens, J., Casimir, A. Ebinghaus, R., Edwards, G., Fitzgerald, C., Kemp, J., Kock, H.H., London, J., Majewski, M., Poissant, L., Pilote, M., Rasmussen, P., Schaedlich, F., Schneeberger, D., Sommar, J., Turner, R., Wallschlager, D., Xiao, Z., 1999. Increases in mercury emissions from desert soils in response to rainfall and irrigation. Journal of Geophysical ResearchAtmospheres 104, 21879-21888.

Mao, I.F., Chen, L.T., Wang, Y.N., Yang, S.F., Chen, H.C., Chen, M.L., 2005. The temporal and spatial variations of acid aerosols in the Geothermal Area of metropolitan Taipei, Taiwan. Archives of Environmental Contamination and Toxicology 49, 141-149.

Mason, R.P., Fitzgerald, W.F., Morel, F.M.M., 1994. The biogeochemical cycling of elemental mercury: anthropogenic influences. Geochimica et Cosmochimica Acta 58 (15), 3191-3198

Poissant, L., Casimir, A., 1998. Water-air and soil-air exchange rate of total gaseous mercury measured at background sites. Atmospheric Environment 32, 883-893.

Pyle, D.M., Mather, T.A., 2003. The importance of volcanic emissions for the global atmospheric mercury cycle. Atmospheric Environment 37 (36), 5115-5124.
Schroeder, W.H., Keeler, G., Kock, H., Roussel, P., Schneeberger, D., Schaedlich, F., 1995. International field intercomparison of atmospheric mercury measurement methods. Water, Air, \& Soil Pollution 80 (1), 611-680.

Shinohara, H., 2005. A new technique to estimate volcanic gas composition: plume measurements with a portable multi-sensor system. Journal of Volcanology and Geothermal Research 143 (4), 319-333.

Shinohara, H., Witter, J.B., 2005. Volcanic gases emitted during mild Strombolian activity of Villarrica volcano, Chile. Geophysical Research Letters 32 (20), L20308.

Shinohara, H., Kazahaya, K., Saito, G., Fukui, K., Odai, M., 2003. Variation of $\mathrm{CO}_{2} / \mathrm{SO}_{2}$ ratio in volcanic plumes of Miyakejima: stable degassing deduced from heliborne measurements. Geophysical Research Letters 30 (5). doi:10.1029/2002GL016105.

Sholupov, S., Pogarev, S., Ryzhov, V., Mashyanov, N., Stroganov, A., 2004. Zeeman atomic absorption spectrometer RA-915+ for direct determination of mercury in air and complex matrix samples. Fuel Processing Technology 85, 473-485.

Song, S.R., Yang, T.F., Yeh, Y.H., Tsao, S.J., Lo, H.J., 2000. The Tatun volcano group is active or extinct? Proceedings of the Geological Society of China 43, 521-534.

Varekamp, J.C., Buseck, P.R., 1981. Mercury emissions from Mount St Helens during September 1980. Nature 293, 555-556.

Varekamp, J.C., Buseck, P.R., 1986. Global mercury flux from volcanic and geothermal sources. Applied Geochemistry 1 (1), 65-73.

Witt, M.L.I., Mather, T.A., Pyle, D.M., Aiuppa, A., Bagnato, E., Tsanev, V.I., 2008. Mercury and halogens from Masaya and Telica volcanoes, Nicaragua. JGR Solid Earth 113, B06203. doi:10.1029/2007JB005401.

Yang, T.F., Sano, Y., Song, S.R., 1999. He-3/He-4 ratios of fumaroles and bubbling gases of hot springs in Tatun Volcano Group, North Taiwan. Nuovo Cimento Della Societa Italiana Di Fisica C-Geophysics and Space Physics 22 (3-4), 281-286.

Yang, T.F., Ho, H.H., Hsieh, P.S., Lin, N.J., Chen, Y.G., Chen, C.H., 2003. Compositions and sources of fumarolic gases from Tatun Volcano Group, North Taiwan. Journal of National Parks 13 (1), 127-156 (in Chinese).

Zimmer, M.M., Fischer, T.P., Hilton, D.R., Alvarado, G.E., Sharp, Z.D., Walker, J.A., 2004. Nitrogen systematics and gas fluxes of subduction zones: insights from Costa Rica arc volatiles. Geochemistry Geophysics Geosystems 5. doi:10.1029/2003GC000651. 